\title{
ANALISIS LAPORAN KEUANGAN
}

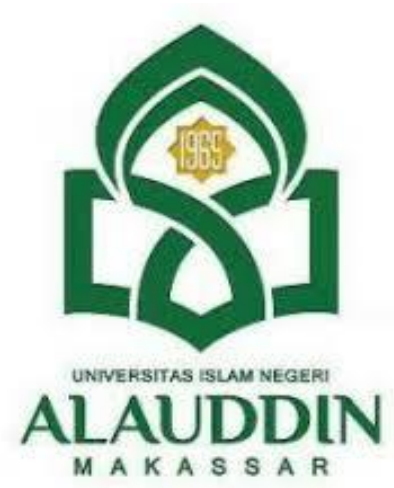

\section{MAKALAH}

Dipresentasikan Pada Mata Kuliah Analisis Laporan Keuangan Program Studi Perbankan Syariah Semester V Tahun 2021

Oleh :

KELOMPOK 1 (Kelas C)

1. Siti Alwiyah (90500119066)

2. Muhammad Zaifuddin (90500119075)

3. Warda (90500119077)

\section{Dosen Pengajar :}

Ismawati, S.E.,M.Si

\section{PROGRAM STUDI PERBANKAN SYARIAH FAKULTAS EKONOMI DAN BISNIS ISLAM UIN ALAUDDIN MAKASSAR}




\section{KATA PENGANTAR}

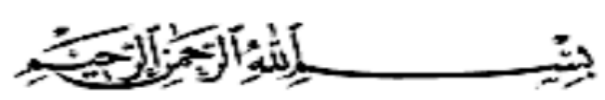

Puji syukur Penyusun panjatkan kepada Allah S.W.T, yang telah melimpahkan rahmat, hidayah dan karunianya, sehingga penyusun dapat menyelesaikan makalah Analisis Laporan Keuangan dengan judul "Analisis Laporan Keuangan”.

Makalah ini ini disusun atas dasar untuk memenuhi tugas mata kuliah Analisis Laporan Keuangan. Tidak lupa penyusun mengucapkan banyak-banyak terima kasih kepada segenap pihak yang telah membantu dan memberikan bimbingan serta arahan selama penulisan makalah ini.

Penyusun menyadari bahwa makalah ini masih jauh dalam kesempurnaan, oleh karena itu kritik dan saran yang membangun sangat penyusun harapkan demi kesempurnaan makalah ini.

Akhir kata, Penyusun mohon maaf yang sebesar-besarnya apabila dalam penyusunan makalah ini terdapat banyak kesalahan. Semoga makalah ini dapat bermanfaat khususnya bagi penyusun dan umumnya bagi para pembaca.

Makassar, 5 Oktober 2021

Penyusun

Kelompok 1 


\section{DAFTAR ISI}

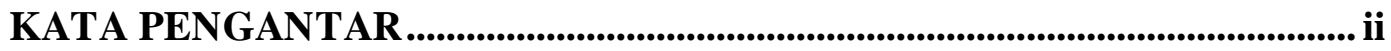

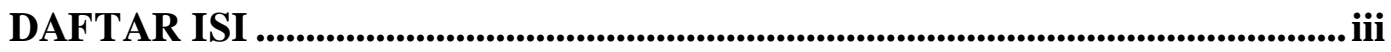

\section{BAB I}

PENDAHULUAN ................................................................................................................ 1

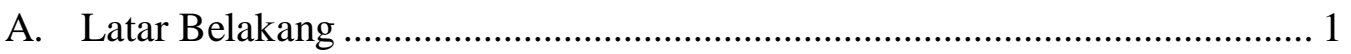

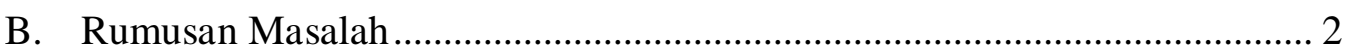

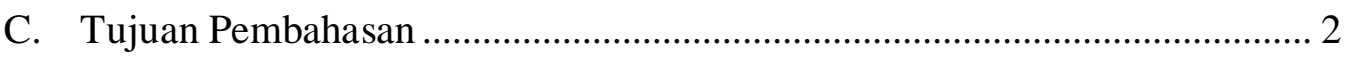

\section{BAB II}

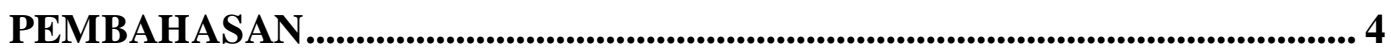

A. Pengertian Analisis Laporan Keuangan ..................................................... 4

B. Tujuan Dan Manfaat Analisis ........................................................................... 5

C. Bentuk-Bentuk dan Teknik Analisis................................................................. 6

D. Analisis Perbandingan Laporan Keuangan ................................................ 9

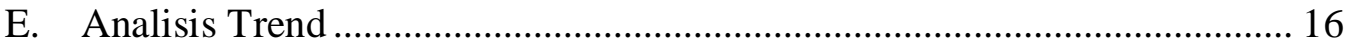

F. Analisis Persentase Perkomponen ............................................................. 23

\section{BAB III}

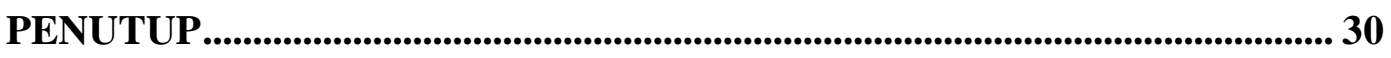

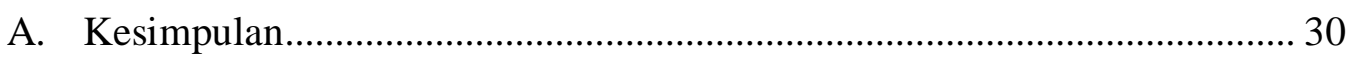

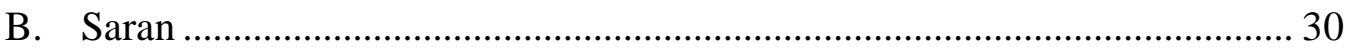

DAFTAR PUSTAKA ................................................................................................ 31 


\section{BAB I \\ PENDAHULUAN}

\section{A. Latar Belakang}

Analisis laporan keuangan adalah suatu proses penelitian laporan keuangan beserta unsure-unsurnya yang bertujuan untuk mengevaluasi dan memprediksi kondisi keuangan perusahaan atau badan usaha dan juga mengevaluasi hasilhasil yang telah dicapai perusahaan atau badan usaha pada masa lalu dan sekarang.

Analisis terhadap laporan keuangan suatu perusahaan pada dasarnya karena ingin mengetahui tingkat keuntungan dan tingkat risiko dan tingkat kesehatan suatu perusahaan.

Analisis terhadap laporan keuangan suatu perusahaan pada dasarnya karena ingin mengetahui tingkat keuntungan dan tingkat risiko dan tingkat kesehatan suatu perusahaan. Analisis semacam ini mengharuskan seorang analis untuk melakukan beberapa hal :

1) Menentukan dengan jelas tujuan analisis.

2) Memahami konsep-konsep dan prinsip-prinsip yang mendasari laporan keuangan dan rasio-rasio keuangan yang diturunkan dari laporan keuangan tersebut.

3) Memahami kondisi perekonomian dan kondisi bisnis lain pada umumnya yang berkaitan dengan perusahaan dan mempengaruhi usaha perusahaan.

Sebelum melakukan analisis seorang analis harus memahami ketiga langkah diatas,baru kemudian melakukan analisis dengan menggunakan alat-alat analisis seperti rasio-rasio keuangan atau rasio-rasio lainnya.

Dalam melakukan analisis terhadap laporan keuangan tersebut diperlukan beberapa tolak ukur. Analisis yang biasa dipakai adalah rasio atau indeks yang merupakan perbandingan di antara data-data keuangan. Analisis rasio keuangan merupakan alat utama yang dapat digunakan dalam melakukan analisis terhadap laporan keuangan. 
Melalui analisis rasio dapat dihasilkan pengukuran dalam bentuk rasio atau relatif dan bukan dalam angka yang absolut. Dengan demikian dapat mempermudah dalam melihat perubahanperubahan yang terjadi, apakah menunjukkan arah yang tetap, meningkat atau bahkan menurun. Faktor-faktor yang paling utama untuk mendapatkan perhatian analisis adalah tingkat likuiditas, profitabilitas atau rentabilitas, solvabilitas dan aktivitas. Likuiditas dapat menunjukkan kemampuan suatu perusahaan untuk memenuhi kewajiban keuangannya yang harus segera dipenuhi atau kemampuan perusahaan untuk memenuhi kewajiban keuangannya pada saat ditagih. Profitabilitas dapat menunjukkan kemampuan perusahaan untuk menghasilkan laba selama periode tertentu.

Solvabilitas dapat menunjukkan kemampuan perusahaan untuk memenuhi kewajiban keuangannya apabila perusahaan tersebut dilikuidasikan, baik kewajiban jangka pendek maupun kewajiban jangka panjang. Aktivitas dapat mengukur sejauh mana efektivitas perusahaan dalam menggunakan sumber dayanya.

\section{B. Rumusan Masalah}

1. Mendefenisikan pengertian analisis laporan keuangan.

2. Menjelaskan tujuan dan manfaat analisis laporan keuangan.

3. Menggambarkan bentuk-bentuk dan teknis analisis laporan keuangan.

4. Menggambarkan analisis perbandingan laporan keuangan.

5. Menjelaskan analisis trend.

6. Mendiskusikan analisis trend prsentase per komponen.

7. Menggambarkan seluruh isi bab ini dan sekaligus mampu untuk mendiskusikannya.

\section{Tujuan Pembahasan}

1. Dapat mengetahui pengetian Analisis Laporan Keuangan.

2. Dapat mengetahui Tujuan dan Manfaat Analisis.

3. Dapat mengetahui Bentuk-Bentuk dan Teknis Analisis. 
4. Dapat mengetahui Analisis Perbandingan Laporan Keuangan.

5. Dapat mengetahui Analisis Trend.

6. Dapat mengetahui Analisis Presentase Per Komponen.

7. Dapat mengetahui seluruh isi bab ini dan sekaligus mampu untuk mendiskusikannya. 


\section{BAB II \\ PEMBAHASAN}

\section{A. Pengertian Analisis Laporan Keuangan}

Setelah laporan keuangan disusun berdasarkan an-nur data yang relevan, serta dilakukan dengan prosedur akuntansi dan penilaian yang benar, ar akan terlihat kondisi keuangan perusahaan yang sesungguhnya. Kondisi keuangan yang dimaksud adalah diketahuinya beberapa jumlah harta kekayaan utang serta modal dalam neraca yang dimiliki. Kemudian an juga akan diketahui jumlah pendapatan yang diterima dan jumlah biaya yang dikeluarkan selama periode tertentu. Dengan demikian an8 diketahui bagaimana hasil usaha laba atau rugi yang diperoleh selama periode tertentu dari laporan laba rugi yang disajikan.

Agar laporan keuangan menjadi lebih berarti sehingga dapat dipahami dan dimengerti oleh berbagai pihak, perlu dilakukan analisis laporan keuangan. Bagi pihak pemilik dan manajemen, tujuan utama analisis laporan keuangan adalah agar dapat mengetahui posisi keuangan perusahaan saat ini. Dengan mengetahui posisi keuangan, setelah dilakukan analisis laporan keuangan secara mendalam, dapat mencapai target yang dapat mencapai target yang telah direncanakan sebelumnya atau tidak.

Hasil analisis ini juga akan memberikan informasi tentang kelemahan dan kekuatan yang dimiliki perusahaan. Dengan mengetahui kelemahan ini, manajemen akan dapat memperbaiki atau menutupi kelemahan tersebut. Kemudian kekuatan yang dimiliki perusahaan harus dipertahankan atau bahkan ditingkatkan. Kekuatan ini dapat dijadikan modal selanjutnya ke depan. Dengan adanya kelemahan dan kekuatan yang dimiliki akan tergambar kinerja manajemen selama ini.

Pada akhirnya bagi pihak pemilik dan manajemen, dengan mengetahui posisi keuangan dapat merencanakan dan mengambil keputusan yang tepat tentang apa yang harus dilakukan kedepan. Perencanaan kedepan dengan cara menutupi kelemahan yang ada mempertahankan posisi yang sudah sesuai dengan 
yang diinginkan dan berupaya untuk meningkatkan lagi kekuatan sudah diperolehnya selama ini.

Analisis laporan keuangan perlu dilakukan secara cermat dengan menggunakan metode dan teknik analisis yang tepat sehingga hasil yang diharapkan benar-benar tepat pula. Kesalahan dalam memasukkan angka atau rumus akan berakibat pada tidak akuratnya hasil yang hendak dicapai. Kemudian hasil perhitungan tersebut dianalisis dan diinterpretasikan sehingga diketahui posisi keuangan yang sesungguhnya. Ketemuan teliti mendalam dan jujur.

\section{B. Tujuan Dan Manfaat Analisis}

Kegiatan dalam analisis laporan keuangan dapat dilakukan dengan cara menentukan dan mengukur antara pos-pos yang ada dalam suatu laporan keuangan. Kemudian analisis laporan keuangan juga dapat dilakukan dengan menganalisis laporan keuangan yang dimiliki dalam satu periode. Disamping itu analisis laporan keuangan dapat dilakukan pula antara beberapa periode misalnya 3 tahun.

Analisis laporan keuangan yang dilakukan untuk beberapa periode adalah menganalisis antara pos-pos yang ada dalam satu laporan. Atau dapat pula dilakukan antara satu laporan dengan laporan yang lainnya. Hal ini dilakukan agar lebih tepat dalam menilai kemajuan atau kinerja manajemen dari periode ke periode selanjutnya.

Ada beberapa tujuan dan manfaat bagi berbagai pihak dengan adanya analisis laporan keuangan. Secara umum dikatakan bahwa tujuan dan manfaat analisis laporan keuangan adalah:

1. Untuk mengetahui posisi keuangan perusahaan dalam suatu periode tertentu baik harta kewajiban modal maupun hasil usaha yang telah dicapai untuk beberapa periode.

2. Untuk mengetahui kelemahan-kelemahan apa saja yang menjadi kekurangan perusahaan.

3. Untuk mengetahui kekuatan kekuatan yang dimiliki. 
4. Untuk mengetahui langkah-langkah perbaikan apa saja yang perlu dilakukan ke depan yang berkaitan dengan posisi keuangan perusahaan saat ini.

5. Untuk melakukan penilaian kinerja manajemen ke depan apakah perlu penyegaran atau tidak karena sudah dianggap berhasil atau gagal.

6. Dapat juga digunakan sebagai pembanding dengan perusahaan sejenis tentang hasil yang mereka capai.

\section{Bentuk-Bentuk dan Teknik Analisis}

Untuk melakukan analisis laporan keuangan diperlukan metode dan teknik analisis yang tepat. Tujuan penentuan metode dan teknik analisis yang dapat yang tepat adalah agar laporan keuangan tersebut dapat memberikan hasil yang maksimal. Selain itu para pengguna hasil analisis tersebut dapat dengan mudah untuk menginterpretasikannya.

Sebelum melakukan analisis laporan keuangan diperlukan langkah-langkah atau prosedur tertentu langkah atau prosedur ini diperlukan agar urutan proses analisis mudah untuk dilakukan.

Adapun langkah atau prosedur yang dilakukan dalam analisis keuangan adalah

1. Mengumpulkan data keuangan dan data pendukung yang diperlukan selengkap mungkin baik untuk satu periode maupun beberapa periode .

2. Melakukan pengukuran pengukuran atau perhitungan perhitungan dengan rumus-rumus tertentu sesuai dengan standar yang biasa digunakan secara cermat dan teliti sehingga hasil yang diperoleh benar-benar tepat.

3. Melakukan perhitungan dengan memasukkan angka-angka yang ada dalam laporan keuangan secara cermat.

4. Melakukan interpretasi terhadap hasil perhitungan dan pengukuran yang telah dibuat.

5. Membuat laporan tentang posisi keuangan perusahaan.

6. Memberikan rekomendasi yang dibutuhkan sehubungan dengan hasil analisis tersebut. 
Dalam praktiknya terdapat dua macam metode analisis laporan keuangan yang bisa dipakai yaitu sebagai berikut

\section{Analisis Vertikal (Statis)}

Analisis vertikal merupakan analisis yang dilakukan terhadap hanya satu periode laporan keuangan saja analisis dilakukan antara pos-pos yang ada dalam satu periode informasi yang diperoleh hanya untuk satu periode saja dan tidak diketahui perkembangan dari periode ke periode tidak diketahui.

2. Analisis Horizontal (Dinamis)

Analisis horizontal merupakan analisis yang dilakukan dengan membandingkan laporan keuangan untuk beberapa periode dari hasil analisis ini akan terlihat perkembangan perusahaan dari periode yang satu ke periode yang lain.

Kemudian di samping metode yang digunakan untuk menganalisis laporan keuangan terdapat beberapa jenis-jenis teknik analisis laporan keuangan adapun jenis-jenis teknik analisis laporan keuangan yang dapat dilakukan adalah sebagai berikut

1. Analisis Perbandingan Antara Laporan Keuangan

2. Analisis Trend

3. Analisis Persentase Perkomponen

4. Analisis Sumber Dan Penggunaan Dana

5. Analisis Sumber Dan Penggunaan Kas

6. Analisis Rasio

7. Analis Kredit

8. Analisis Laba Kotor

9. Analisis Titik Pulang Pokok atau Titik Impas (break even point)

Analisis perbandingan antara laporan keuangan merupakan analisis ini dilakukan dengan membandingkan laporan keuangan lebih dari satu periode artinya minimal dua periode atau lebih dari analisis ini akan dapat diketahui perubahan-perubahan yang terjadi perubahan yang terjadi dapat berupa kenaikan atau penurunan dari masing-masing komponen analisis dari perubahan ini terlihat 
masing-masing kemajuan atau kegagalan-kegagalan dalam mencapai target yang telah ditetapkan sebelumnya

Secara umum dari hasil analisis analisis ini akan terlihat antara lain

a. Angka-Angka Dalam Rupiah;

b. Angka-Angka Dalam Persentase;

c. Kenaikan Atau Penurunan Jumlah Rupiah;

d. Kenaikan Atau Penurunan Baik Dalam Rupiah Maupun Dalam Persentase.

Analisis trend atau tendensi merupakan analisis laporan keuangan yang biasanya dinyatakan dalam presentasi tersebut analisis ini dilakukan dari periode ke periode sehingga akan terlihat apakah perubahan mengalami perubahan yaitu naik turun atau tetap serta seberapa besar perubahan tersebut yang dihitung dalam persentase.

Analisis persentase perkomponen merupakan analisis yang dilakukan untuk membandingkan antara komponen yang ada dalam suatu laporan keuangan baik yang ada di neraca maupun laporan laba rugi.

Analisis ini dilakukan untuk mengetahui

a. Persentase Investasi Terhadap Masing-Masing Aktiva Atau Terhadap Total Aktiva

b. Struktur Permodalan

c. Komposisi Biaya Terhadap Penjualan

Analisis sumber dan penggunaan dana merupakan analisis yang dilakukan untuk mengetahui sumber-sumber dana perusahaan dan penggunaan dana dalam suatu periode analisis ini juga untuk mengetahui jumlah modal kerja dan sebabsebab berubahnya modal kerja perusahaan dalam satu periode.

Analisis sumber dan penggunaan kas merupakan analisis yang digunakan untuk mengetahui sumber-sumber kas perusahaan dan penggunaan uang kas dalam suatu periode setelah itu juga untuk mengetahui sebab-sebab berubahnya jumlah uang kas dalam periode tertentu.

Analisis rasio merupakan analisis yang digunakan untuk mengetahui hubungan pos-pos yang ada dalam suatu laporan keuangan atau pos-pos antara laporan keuangan neraca dan laporan laba rugi. 
Analisis kredit merupakan analisis yang digunakan untuk menilai layak tidaknya suatu kredit dikucurkan oleh lembaga keuangan seperti bank dalam analisis ini digunakan beberapa cara alat analisis yang digunakan.

Analisis laba kotor merupakan analisis yang digunakan untuk mengetahui jumlah laba kotor dari periode ke satu periode kemudian juga untuk mengetahui sebab-sebab perubahannya laba kotor tersebut antara periode.

Analisis titik pulang pokok disebut juga analisis. Impas atau break even point tujuan analisis ini adalah untuk mengetahui pada kondisi beberapa penjualan produk dilakukan dan perusahaan tidak mengalami kerugian kegunaan analisis ini adalah untuk menentukan jumlah keuntungan pada berbagai tingkat penjualan.

\section{Analisis Perbandingan Laporan Keuangan}

Laporan keuangan adalah dapat dilakukan dengan dua model yaitu pertama analisis horizontal atau analisis dinamis dan kedua analisis vertikal atau analisis statis dalam analisis horizontal yang dibandingkan adalah laporan keuangan untuk beberapa periode sedangkan analisis vertikal adalah jika kita hanya membandingkan satu pos dengan pos yang lain dalam suatu laporan keuangan dan hanya meliputi satu periode laporan keuangan.

Ada beberapa keuntungan yang diperoleh dari analisis horizontal jika dibandingkan dengan analisis vertikal dalam analisis horizontal kita kan atau terjadinya perubahan-perubahan terhadap komponen laporan keuangan dari periode ke periode lain seperti misalnya kenaikan atau penurunan komponenkomponen yang ada di laporan keuangan sementara itu dalam analisis statis hal tersebut tidak terlihat kemudian laporan analisis horizontal akan mempermudah kita untuk mengambil keputusan hal-hal apa saja yang perlu dilakukan sehubungan dengan perubahan yang terjadi.

Perubahan yang terjadi perlu diketahui untuk melihat perkembangan keadaan keuangan atau suatu perusahaan setelah perubahan ini diketahui apakah terjadi kenaikan atau penurunan atau tetap dapat pula diketahui sebab-sebab terjadi perubahan tersebut. 
Perubahan dalam laporan keuangan neraca untuk satu periode dapat disebabkan oleh berbagai faktor misalnya :

1. Ada perolehan aktiva baru;

2. Adanya pengurangan aktiva seperti pelunasan utang piutang;

3. Berubahnya bentuk aktif dari tetap lancer;

4. Adanya perubahan yang adanya perubahan yang diakibatkan oleh laba rugi laba rugi perusahaan dan biaya-biaya yang dikeluarkan;

5. Adanya penambahan atau pengurangan modal saham; dan

6. Perubahan lainnya.

Dari hasil analisis perbandingan laporan keuangan ini dapat diketahui sifat dan tendensi perubahan yang terjadi kemudian hasil analisis ini dapat ditunjukkan dalam bentuk :

1. Jumlah dalam rupiah;

2. Jumlah penurunan dalam rupiah;

3. Jumlah kenaikan dalam rupiah;

4. Perbandingan dalam persentase;

5. Perbandingan dalam bentuk rasio.

Agar analisis perbandingan laporan keuangan dapat dilakukan dengan baik maka perlu dibuatkan kolom-kolom terlebih dulu tujuannya adalah agar lebih mudah untuk melihat dan membandingkan satu sama lainnya bentuk kolom kolom dapat analisis perbandingan secara horizontal dapat dilakukan dengan berbagai cara salah satunya adalah sebagai berikut.

\author{
PT RAY IBRAHIM, Tbk \\ NERACA PERBANDINGAN
}

Per 31 Desember 2006 dan 2007 (dalam jutaan) 


\begin{tabular}{|c|c|c|c|c|c|}
\hline \multirow[b]{2}{*}{$\begin{array}{c}\text { Pos-pos dalam } \\
\text { Neraca }\end{array}$} & \multicolumn{2}{|c|}{ Pertode } & \multicolumn{2}{|c|}{ NalkJ Turun } & \multirow[b]{2}{*}{ Raslo } \\
\hline & $\begin{array}{l}\text { Tahun } \\
2006\end{array}$ & $\begin{array}{c}\begin{array}{c}\text { Tahun } \\
2007\end{array} \\
\end{array}$ & Ruplah & $\%$ & \\
\hline Aktlva lancar & & & & & \\
\hline Kas & 250 & 350 & 100 & 40,0 & 1,4 \\
\hline Giro & 175 & 200 & 25 & 14,3 & 1.14 \\
\hline Surat-surat berharga & 140 & so & (90) & $(64.3)$ & 0.35 \\
\hline Piutang & 350 & 250 & $(100)$ & $(28,6)$ & 0,71 \\
\hline Sediaan & 125 & 150 & 25 & 20,0 & 1,2 \\
\hline $\begin{array}{l}\text { Total aktiva Lancar } \\
\text { Aktiva tetap }\end{array}$ & 1.040 & 1.000 & 40 & 3,9 & 0,96 \\
\hline Tanah & 3.000 & 4.200 & 1.200 & 40,0 & 1,4 \\
\hline Mesin & 2.500 & 3.500 & 1.000 & 40,0 & 1,4 \\
\hline Kendaraan & 1.500 & 1.000 & $(500)$ & $(33,3)$ & 0,66 \\
\hline Akumulasi pernyusutan & $(400)$ & $(450)$ & 50 & 12,5 & 1,125 \\
\hline $\begin{array}{l}\text { Total aktiva tetap } \\
\text { Aktiva lainnya }\end{array}$ & 6.600 & 8.250 & 1.650 & 25,5 & 1,25 \\
\hline Tofal aktiva lainnya & 360 & 250 & (90) & $(25,0)$ & 0,69 \\
\hline $\begin{array}{l}\text { Total aktiva } \\
\text { Utang lancar }\end{array}$ & 8.000 & 9.500 & 1500 & 18,8 & 1,18 \\
\hline Utang bark & 550 & 250 & (300) & $(54,6)$ & 0.45 \\
\hline Utang dagang & 100 & 200 & 100 & 100 & 2,0 \\
\hline Utang wesel & 100 & 0 & $(100)$ & $(100)$ & 0 \\
\hline Utang lainnya & 50 & 100 & 50 & 100 & 2,0 \\
\hline $\begin{array}{l}\text { Total utang lancar } \\
\text { Utang Jangka panjang }\end{array}$ & 800 & 550 & $(250)$ & $(31,3)$ & 0,68 \\
\hline Utang bank 3 tahun & 2.750 & 1.950 & $(800)$ & $(29,0)$ & 0.71 \\
\hline Utang obligast & 2.000 & 1.450 & (550) & $(27,5)$ & 0,72 \\
\hline Utang hipotek & 0 & 1.550 & 1.550 & 100 & $=$ \\
\hline $\begin{array}{l}\text { Total utang fangka } \\
\text { panjang }\end{array}$ & 4.750 & 4.950 & (200) & $(0,4)$ & 1,04 \\
\hline Ekuitas & & & & & \\
\hline Modal setor & 2.000 & 2.500 & 500 & 25.0 & 1.25 \\
\hline Cadangan laba & 450 & 1.500 & 1.050 & 233 & 3,33 \\
\hline Total Ekultas & 2.450 & 4.000 & 1.550 & 63,3 & 1,63 \\
\hline Total Passlva & 8.000 & 9.500 & 1500 & 18,8 & 1,18 \\
\hline
\end{tabular}

Berikut adalah perubahan-perubahan yang terjadi dalam pos neraca :

\section{Sisi Aktiva Lancar}

1. Kas terjadi kenaikan sebesar Rp100 atau sekitar $40 \%$ yaitu peningkatan dari tahun 2006 sebesar Rp250 menjadi Rp350 pada tahun 2007.

2. Rekening giro juga terjadi peningkatan sebesar Rp25 atau sekitar 14,3\% dari tahun 2006 sebesar Rp175 menjadi Rp200 pada tahun 2007 hal ini disebabkan karena adanya pembayaran lewat rekening giro dan setoran rekening tersebut.

3. Terjadi penurunan pada surat-surat berharga sebesar Rp90 atau sekitar 64,3\% dari tahun 2006 sebesar Rp140 menjadi Rp50 pada tahun 2007 hal ini 
disebabkan karena adanya pencairan dan penjualan surat-surat berharga yang dimiliki.

4. Terjadi penurunan pada piutang sebesar Rp100 atau sekitar 28,6\% dari tahun 2006 sebesar Rp350 menjadi Rp250 pada tahun 2007 hal ini disebabkan karena adanya pembayaran oleh debitur.

5. Sediaan terjadi peningkatan sebesar Rp25 atau sekitar $20 \%$ dari tahun 2006 sebesar Rp125 menjadi Rp150 pada tahun 2007 hal ini disebabkan adanya pembelian sejumlah bahan baku dan sejumlah barang untuk diperdagangkan.

6. Total aktiva lancar yang terjadi penurunan sebesar Rp40. Atau sekitar 3,9\% dari tahun 2006 sebesar Rp1.040.00 menjadi Rp1.000 ah pada tahun 2007.

\section{Sisi Aktiva Tetap}

1. Terjadi peningkatan pada tanah sebesarsebesar Rp1.200 atau sekitar $40 \%$ dari tahun 2002006 sebesar Rp3.000 menjadi Rp4.200 pada tahun 2007 hal ini disebabkan karena adanya pembelian tanah untuk keperluan perusahaan.

2. Terjadi peningkatan pada mesin sebesar Rp1.000 atau sekitar $40 \%$ dari tahun 2006 sebesar Rp2.500 menjadi Rp3.500 pada tahun 2007 hal ini disebabkan adanya pembelian penambahan mesin baru.

3. Terjadi penurunan pada kendaraan sebesar Rp500 atau sekitar 33,3\% dari tahun 2006 sebesar Rp1.500 menjadi Rp1.000 pada tahun 2007 hal ini disebabkan karena adanya penjualan terhadap kendaraan lama dan ada kendaraan yang umur ekonomisnya sudah berakhir.

4. Akumulasi penyusutan meningkat sebesar Rp50 atau sekitar 12,5\% dari tahun 2006 sebesar Rp400 jadi 450 pada tahun 2007 hal ini disebabkan penambahan aktiva tetap dari mesin.

5. Total aktiva tetap meningkat Rp1.650 atau sekitar 25\% dari tahun 2006 besar Rp6.600 menjadi Rp8.250 pada tahun 2007 hal ini karena penambahan aktiva tetap lebih besar dari yang dikeluarkan.

6. Total aktiva lain menurun sebesar Rp110 atau sekitar 25\% dari tahun 2006 sebesar Rp360 menjadi Rp250 pada tahun 2007 hal ini disebabkan ada 
Sebagian komponen aktiva lainnya sudah selesai seperti bangunan dalam proses.

7. Total aktiva meningkat sebesar Rp1.500 atau sekitar 18,8\% dari tahun 2006 sebesar Rp8.000 menjadi Rp9.500 pada tahun 2007 hal ini disebabkan karena adanya peningkatan jumlah aktiva secara keseluruhan.

\section{Sisi Pasiva Lancar}

1. Utang bank menurun sebesar Rp300 atau sekitar 54,6\% dari tahun 2006 sebesar Rp550 menjadi Rp250 pada tahun 2007 hal ini disebabkan karena adanya pelunasan terhadap utang bank yang sudah jatuh tempo.

2. Utang dagang meningkat sebesar Rp100 atau sekitar 100\% dari tahun 2006 sebesar Rp100 menjadi Rp200 pada tahun 2007 hal ini disebabkan karena adanya penambahan pembelian barang dagangan secara kredit.

3. Utang wesel lunas atau menurun sebesar Rp100 atau sekitar $100 \%$ dari tahun 2006 sebesar Rp100 menjadi Rp0 pada tahun 2007 hal ini disebabkan karena adanya pelunasan terhadap utang tersebut.

4. Utang lainnya meningkat sebesar Rp50 atau sekitar 100\% dari tahun 2006 sebesar Rp50 menjadi Rp100 pada tahun 2007 hal ini disebabkan karena adanya penambahan utang seperti utang gaji dan utang pajak.

5. Uang sebesar Rp250 atau sekitar 31,1\% dari tahun 2006 sebesar Rp800 menjadi Rp550 pada tahun 2007 hal ini disebabkan karena adanya utang yang sudah jatuh tempo atau lunas lebih besar ketimbang memperoleh utang baru.

\section{Sisi Utang Jangka Panjang}

1. Utang bank 3 tahun menurun sebesar Rp800 atau sekitar 29\% dari tahun 2006 sebesar Rp2.750 menjadi Rp1.950 pada tahun 2007 hal ini disebabkan karena sebagai utang sudah lunas.

2. Utang obligasi menurun sebesar Rp550 atau sekitar 27,5\% dari tahun 2006 sebesar Rp.2.000 menjadi Rp1.450 pada tahun 2007 hal ini disebabkan karena adanya pelepasan obligasi.

3. Terjadi penambahan pada hutang hipotek sebesar Rp1.550 atau sekitar $100 \%$ dari tahun 2006 sebesar Rp0 menjadi Rp1.550 pada tahun 2007 hal ini 
disebabkan karena adanya penambahan utang hipotek dengan jaminan aktiva tetap perusahaan selama 5 tahun.

4. Total utang jangka panjang menurun sebesar Rp200 atau sekitar 4\% dari tahun 2006 sebesar Rp.4.750 menjadi Rp4.950 pada tahun 2007 hal ini disebabkan karena adanya penambahan utang jangka panjang lebih kecil ketimbang pelunasannya.

\section{Sisi Ekuitas}

1. Modal setor meningkat sebesar Rp500 atau sekitar 25\% dari tahun 2006 sebesar Rp2.000 menjadi Rp2.500 pada tahun 2007 hal ini disebabkan karena adanya tambahan modal dari penjualan saham.

2. Cadangan laba meningkat sebesar Rp1.050 atau sekitar 23,3\% dari tahun 2006 sehingga sebesar Rp450 menjadi Rp1.500 pada tahun 2007 hal ini disebabkan karena jumlah cadangan dari tahun sebelumnya ditambah cadangan sekarang.

3. Total ekuitas meningkat sebesar Rp1.550 atau sekitar 63,3\% dan tahun 2006 sebesar Rp2.450 menjadi Rp4.000 pada tahun 2007 hal ini disebabkan karena semua komponen ekuitas seperti modal setor dan cadangan laba meningkat.

4. Total aktiva meningkat sebesar Rp1.500 atau sekitar 18,8\% dari tahun 2006 sebesar Rp8.000 menjadi Rp9.500 pada tahun 2007 hal ini disebabkan karena sebagian utang berkurang jumlahnya ketimbang bertambahnya ekuitas.

PT RAY IBRAHIM, Tbk

Laporan Laba Rugi Perbandingan

Per 31 Desember 2006 dan 2007 (dalam ribuan) 


\begin{tabular}{|c|c|c|c|c|}
\hline $\begin{array}{l}\text { Komponen } \\
\text { Laporan } \\
\text { Laba Rugi }\end{array}$ & $\begin{array}{l}\text { Tahun } \\
2006\end{array}$ & $\begin{array}{l}\text { Tahun } \\
2007\end{array}$ & $\begin{array}{l}\text { Naik } \\
\text { (Turun) }\end{array}$ & Dalam \\
\hline Total penjualan & 8.500 .000 & 9.900 .000 & 1.400 .000 & 16,5 \\
\hline $\begin{array}{l}\text { Harga pokok } \\
\text { penjualan }\end{array}$ & 6.250 .000 & 7.350 .000 & 1.100 .000 & 17,8 \\
\hline $\begin{array}{l}\text { Laba Kotor } \\
\text { Biaya Operasl }\end{array}$ & 2.250 .000 & 2.550 .000 & 300.000 & 13,3 \\
\hline $\begin{array}{l}\text { Bjaya umum } 8 \\
\text { administrasi }\end{array}$ & 1.000 .000 & 1.100 .000 & 100.000 & 10,0 \\
\hline $\begin{array}{l}\text { Biaya Penjualan } \\
\text { Biaya faìnnya }\end{array}$ & 50.000 & 75.000 & 25.000 & 50,0 \\
\hline Biaya faìrnya & 15.000 & 20.000 & 5.000 & 33,3 \\
\hline $\begin{array}{ll}\text { Total } & \text { Bìaya } \\
\text { Operasi } & \end{array}$ & 1.065 .000 & 1.195 .000 & 130.000 & 12,2 \\
\hline $\begin{array}{ll}\text { Laba } & \text { Kotor } \\
\text { OperasI } & \end{array}$ & 1.185 .000 & 1.355 .000 & 170.000 & 14,4 \\
\hline $\begin{array}{l}\text { Penyusutan } \\
\text { Pendapatan bersih } \\
\text { operasi }\end{array}$ & $\begin{array}{l}400.000 \\
785.000\end{array}$ & $\begin{array}{l}450.000 \\
905.000\end{array}$ & $\begin{array}{c}50.000 \\
120.000\end{array}$ & $\begin{array}{l}12,5 \\
15,3\end{array}$ \\
\hline $\begin{array}{l}P \text { end a p a t a n } \\
\text { lainnya }\end{array}$ & 165.000 & 175.000 & 10.000 & 6.0 \\
\hline $\begin{array}{l}\text { EBIT } \\
\text { Biaya Bunga }\end{array}$ & 950.000 & 1.080 .000 & 230.000 & 24,2 \\
\hline Bunga bank & 200.000 & 150.000 & $(50.000)$ & $(25,0)$ \\
\hline Bunga obligasi & 50.000 & 30.000 & $(20.000)$ & $(40,0)$ \\
\hline Total Biaya Bunga & 250.000 & 130.000 & $(70.000)$ & $(28,0)$ \\
\hline $\begin{array}{l}\text { EBT } \\
\text { Palak 20\% }\end{array}$ & $\begin{array}{l}700.000 \\
120.000\end{array}$ & 900.000 & 300.000 & 42,9 \\
\hline $\begin{array}{l}\text { Pajak } 20 \% \\
\text { EAIT } \\
\text { Earning per Share }\end{array}$ & 580.000 & $\begin{array}{l}180.000 \\
720.000\end{array}$ & $\begin{array}{l}60.000 \\
\mathbf{2 4 0 . 0 0 0}\end{array}$ & $\begin{array}{l}50 \\
50\end{array}$ \\
\hline
\end{tabular}

Berikut adalah perubahan-perubahan yang terjadi dalam pos-pos laporan laba rugi:

1. Penjualan meningkat $\operatorname{Rp} 1.400 .000$ atau sebesar $16,5 \%$ dari tahun 2006 sebesar Rp8.500.000 menjadi Rp9.900.000 pada tahun 2007 hal ini disebabkan karena adanya penambahan barang yang dijual dan laku di pasaran.

2. Harga pokok penjualan meningkat Rp1.100.000 atau sebesar 17,6\% dari tahun 2006 sebesar Rp6.250.000 menjadi Rp7.350.000 pada tahun 2007 hal ini disebabkan seiring dengan meningkatkan meningkatnya penjualan.

3. Laba kotor meningkat Rp300.000 atau sebesar 13,3\% dari tahun 2006 sebesar Rp2.250.000 menjadi Rp2.550.000 pada tahun 2007 hal ini disebabkan karena penjualan yang meningkat. 
4. Total biaya operasi meningkat Rp130.000 atau sebesar 12,2\% dari tahun 2006 sebesar Rp1.605.000 menjadi Rp1.195.000 pada tahun 2007 hal ini disebabkan karena adanya penambahan biaya seperti biaya administrasi dan umum biaya penjualan dan biaya lainnya.

5. Laba kotor operasi meningkat Rp170.000 atau sebesar 14,4\% dari tahun 2006 sebesar Rp1.185.000 menjadi Rp1.355.000 pada tahun 2007 hal ini disebabkan karena penjualan yang meningkat.

6. Penyusutan meningkat Rp50.000 atau sebesar 12,5\% dari tahun 2006 sebesar Rp400.000 menjadi Rp450.000 pada tahun 2007 hal ini disebabkan karena adanya penambahan aktiva tetap.

7. Pendapat bersih operasi meningkat Rp120.000 atau sebesar 15,3\% dari tahun 2006 sebesar Rp785.000 menjadi Rp905.000 pada tahun 2007 hal ini disebabkan karena adanya peningkatan penjualan.

8. Laba sebelum bunga dan pajak meningkat Rp230.000 atau sebesar $27,1 \%$ dari tahun 2006 sebesar Rp850.000 menjadi Rp1.080.000 pada tahun 2007 hal ini disebabkan karena penjualan yang meningkat.

9. Total biaya bunga menurun Rp250.000 atau sebesar $28 \%$ dari tahun 2006 sebesar Rp250.000 menjadi Rp180.000 pada tahun 2007 hal ini disebabkan karena jumlah utang bank yang berkurang.

10. Laba sebelum pajak meningkat Rp300.000 atau sebesar 50\% dari tahun 2006 sebesar Rp600.000 menjadi Rp900.000 pada tahun 2007 hal ini disebabkan karena meningkatnya penjualan

11. Laba sesudah bunga dan pajak meningkatkan Rp240.000 atau sebesar 50\% dari tahun 2006 sebesar Rp480.000 menjadi Rp720.000 pada tahun 2007 hal ini disebabkan karena meningkatnya penjualan.

\section{E. Analisis Trend}

Analisis trend atau tendensi merupakan analisis laporan keuangan yang biasanya dinyatakan dalam persentase tertentu dalam analisis trend perbandingan analisis dapat dilakukan dengan menggunakan analisis horizontal atau dinamis 
dan yang digunakan adalah data tahunan atau periode yang digunakan biasanya hanya dua atau tiga periode saja hal ini disebabkan karena jika lebih dari 3 periode akan mengalami kesulitan untuk menganalisisnya lebih cepat.

Jika data yang digunakan lebih dari dua atau tiga periode metode yang digunakan adalah angka indeks dengan menggunakan angka indeks akan dapat diketahui kecenderungan atau trend atau arah dari posisi keuangan apakah meningkat menurun atau tetap hasil analisis trend biasanya dihitung dalam persentase.

Data keuangan yang akan digunakan untuk mengadakan analisis trend dengan persentase adalah data yang paling awal kemudian data tersebut dibandingkan dengan data selanjutnya artinya data paling awal dianggap sebagai tahun dasar sebagai awal perhitungan data awal tahun yang akan dianalisis kita anggap data normal di antaranya tahun yang akan dianalisis sebagai contoh kita memiliki data dari tahun 2000 sampai tahun 2006 maka tahun dasar analisis yang akan kita gunakan adalah tahun 2000 .

Angka indeks yang digunakan untuk tiap pos tahun dasar dalam laporan keuangan diberi angka $100 \%$ kemudian pos yang sama dalam periode dihubungkan dengan pos yang sama pula pada tahun berikutnya caranya adalah dengan membagikan jumlah rupiah yang sama tahun yang akan dianalisis dengan pos yang sama dengan tahun dasar.

\author{
PT RAY IBRAHIM, Tbk \\ NERACA PERBANDINGAN
}

Per 31 Desember 2003 dan 2006 


\begin{tabular}{|c|c|c|c|c|c|c|c|}
\hline $\begin{array}{l}\text { Pos-pos } \\
\text { dalam } \\
\text { neraca }\end{array}$ & $\begin{array}{c}\text { Tahun } \\
2003\end{array}$ & \begin{tabular}{|c|} 
Tahun \\
2004
\end{tabular} & \begin{tabular}{|c|} 
Tahun \\
2005
\end{tabular} & $\begin{array}{c}\text { Tahun } \\
2006\end{array}$ & $\begin{array}{c}\text { Trend } \\
\% \\
2004 \\
\end{array}$ & $\begin{array}{c}\text { Trend } \\
\% \\
2005\end{array}$ & $\begin{array}{c}\text { Trend } \\
\% \\
2008\end{array}$ \\
\hline Aktlva lancar & & & & & & & \\
\hline Kas & 100 & 140 & 150 & 80 & 140 & 150 & 80 \\
\hline Plutang & 540 & 680 & 500 & 540 & 126 & 93 & 100 \\
\hline Sediaan & 420 & 560 & 800 & 1.000 & 133 & 191 & 240 \\
\hline $\begin{array}{l}\text { Total Aktiva } \\
\text { Lancar }\end{array}$ & 1.060 & 1.380 & 1.450 & 1.620 & $\uparrow 30$ & 137 & 153 \\
\hline $\begin{array}{l}\text { Total Aktiva } \\
\text { Totap }\end{array}$ & 1.940 & 2.020 & 2.200 & 2.580 & 104 & 113 & 133 \\
\hline Total AktJva & 3.000 & 3.400 & 3.650 & 4.200 & 113 & 122 & 140 \\
\hline $\begin{array}{l}\text { Utang } \\
\text { Jangka } \\
\text { Pendek }\end{array}$ & 500 & 530 & 570 & 600 & 106 & 114 & 120 \\
\hline $\begin{array}{l}\text { Utang } \\
\text { Jangka } \\
\text { Panjang }\end{array}$ & 250 & 250 & 250 & 250 & 100 & 100 & 100 \\
\hline $\begin{array}{l}\text { Total Utang } \\
\text { Ekultas }\end{array}$ & 750 & 780 & 820 & 850 & 104 & 109 & 113 \\
\hline Modal Setor & 2.000 & 2.250 & 2.250 & 2.250 & 113 & 113 & 113 \\
\hline $\begin{array}{l}\text { Cadangan } \\
\text { Laba }\end{array}$ & 250 & 370 & 580 & 1.100 & 148 & 232 & 440 \\
\hline Total Ekuitas & 2.250 & 2.620 & 2.830 & 3.350 & 116 & 126 & 149 \\
\hline Total Passiva & 3.000 & 3.400 & 3.650 & 4.200 & 113 & 122 & \\
\hline
\end{tabular}

Dalam analisis trend harus ditentukan tahun dasar sebagai pembanding baru kemudian dijadikan angka indeksnya rumus untuk mencari angka indeks adalah sebagai berikut:

$$
\text { Angka Indeks }=\frac{\text { Tahun pembandingan }}{\text { Tahun Dasar }} \times 100 \%
$$

Sebagai contoh dari neraca di atas yaitu tahun dasar adalah tahun 2003 sebesar Rp100 dan tahun 2004 Rp140 maka akan indeks adalah

$$
\text { Angka Indeks }=\frac{R p 140,00}{R p 100,00} \times 100 \%=140 \%
$$

Hal ini dapat diartikan sebagai berikut. 
1. Uang kas yang ada pada akhir tahun 2004 sebesar $140 \%$ dari kas yang ada pada tahun 2003 .

2. Uang kas akhir tahun 2004 naik sebesar $40 \%$ jika dibandingkan dengan uang kas akhir tahun 2003.

3. Uang kas akhir tahun 2004 berjumlah 40\% lebih besar dari uang kas akhir tahun 2003.

Kemudian kas akhir tahun 2005 sebesar Rp150 maka :

$$
\text { Angka Indeks }=\frac{R p 150,00}{R p 100,00} \times 100 \%=150 \%
$$

1. Uang kas yang ada pada akhir tahun 2005 sebesar $150 \%$ dari kas akhir tahun 2003.

2. Uang kas akhir tahun 2005 naik sebesar 50\% jika dibandingkan dengan uang tahun 2003.

3. Uang kas akhir tahun 2005 berjumlah $50 \%$ lebih besar dari uang kas akhir tahun 2003.

Selanjutnya khas akhir tahun 2006 sebesar Rp80 maka :

$$
\text { Angka Indeks }=\frac{R p 80,00}{R p 100,00} \times 100 \%=80 \%
$$

1. Uang yang ada pada akhir tahun 2006 hanya sebesar $80 \%$ dari kas akhir tahun 2003.

2. Uang kas akhir tahun 2005 turun $20 \%$ jika dibandingkan dengan uang tahun 2003.

3. Uang kas akhir tahun 2005 berjumlah $20 \%$ lebih kecil dari uang kas akhir tahun 2003.

Dengan demikian pula jumlah piutang di mana ti utang pada akhir tahun 2004 sebesar Rp. 680.000 maka :

$$
\text { Angka Indeks }=\frac{R p 680,00}{R p 540,00} \times 100 \%=126 \%
$$

1. Piutang akhir tahun 2004 hanya sebesar $126 \%$ dari piutang akhir 2003. 
2. Piutang akhir tahun 2004 naik sebesar $26 \%$ jika dibandingkan dengan piutang akhir tahun 2003.

3. Piutang akhir tahun 2004 berjumlah $26 \%$ lebih besar dari piutang akhir tahun 2003.

Selanjutnya untuk piutang pada tahun 2005 sebesar Rp500.000 maka :

$$
\text { Angka Indeks }=\frac{R p 500,00}{R p 540,00} \times 100 \%=93 \% \text { (dibulatkan) }
$$

1. Piutang akhir tahun 2005 hanya sebesar $93 \%$ dari piutang akhir tahun 2003.

2. Piutang akhir tahun 2005 turun sebesar 7\% jika dibandingkan dengan piutang akhir tahun 2003.

3. Piutang akhir tahun 2005 berjumlah 7\% lebih kecil dari piutang akhir tahun 2003.

Sementara itu untuk piutang pada akhir tahun 2006 sebesar rp540.000 maka :

$$
\text { Angka Indeks }=\frac{R p 540,00}{R p 540,00} \times 100 \%=100 \%
$$

1. Piutang akhir tahun 2006 sama dengan piutang akhir tahun 2003.

2. Piutang akhir tahun 2006 tidak mengalami perubahan terhadap piutang akhir tahun 2003.

Pembahasan selanjutnya adalah perhitungan angka indeks untuk laporan laba rugi pada dasarnya perhitungan angka indeks untuk laporan laba rugi tidak berbeda dengan perhitungan di neraca untuk melakukan analisis berikut ini laporan laba rugi yang dimiliki oleh PT Ray Ibrahim Tbk.

PT RAY IBRAHIM, Tbk

LAPORAN LABA RUGI PERBANDINGAN

Per 31 Desember 2003 dan 2006 


\begin{tabular}{|c|c|c|c|c|c|c|c|}
\hline $\begin{array}{l}\text { Pos-pos } \\
\text { laba rugl }\end{array}$ & \begin{tabular}{|c}
$\begin{array}{c}\text { Tahun } \\
2003\end{array}$ \\
\end{tabular} & $\begin{array}{c}\text { Tahun } \\
2004 \\
\end{array}$ & $\begin{array}{c}\text { Tahun } \\
2005 \\
\end{array}$ & $\begin{array}{c}\text { Tahun } \\
2006 \\
\end{array}$ & \begin{tabular}{|l|} 
Trend $\%$ \\
-2004 \\
\end{tabular} & $\begin{array}{c}\text { Trend } \% \\
2005 \\
\end{array}$ & $\begin{array}{c}\text { Trend } \% \\
2036 \\
\end{array}$ \\
\hline Penjualan & 2.600 & 2.850 & 3.000 & 3.400 & 110 & 115 & 131 \\
\hline $\mathrm{HPP}$ & 1.200 & 1.350 & 1.400 & 1.600 & 113 & 117 & 133 \\
\hline $\begin{array}{l}\text { Laba kotor } \\
\text { Blaya } \\
\text { OperasI }\end{array}$ & 1.400 & 1.500 & 1.600 & 1.800 & 107 & 914 & 129 \\
\hline $\begin{array}{l}\text { Biaya } \\
\text { penjualan }\end{array}$ & 500 & 530 & 550 & 570 & 106 & 110 & 114 \\
\hline $\begin{array}{l}\text { Biaya } \\
\text { umum }\end{array}$ & 260 & 270 & 270 & 280 & 104 & 104 & 108 \\
\hline $\begin{array}{l}\text { Total } \\
\text { Blaya } \\
\text { Operasi }\end{array}$ & 760 & 800 & 820 & 850 & 105 & 108 & 112 \\
\hline $\begin{array}{l}\text { Laba } \\
\text { Berslih } \\
\text { Operasl }\end{array}$ & 440 & 700 & 780 & 950 & 159 & 177 & 216 \\
\hline
\end{tabular}

Penjualan pada akhir tahun 2004 sebesar Rp850.000 sedangkan penjualan tahun 2003 adalah Rp2.600 maka :

$$
\text { Angka Indeks }=\frac{R p 2.850,00}{R p 2.600,00} \times 100 \%=110 \%(\text { dibulatkan })
$$

1. Penjualan akhir tahun 2004 sebesar $110 \%$ dari penjualan tahun 2003.

2. Penjualan akhir tahun 2004 naik sebesar 10\% jika dibandingkan dengan penjualan akhir tahun 2003.

3. Penjualan akhir tahun 2004 berjumlah $10 \%$ lebih besar dari penjualan akhir tahun 2003.

Kemudian untuk penjualan pada akhir tahun 2005 sebesar Rp3.000 sedangkan penjualan tahun 2003 adalah Rp2.600 maka :

$$
\text { Angka Indeks }=\frac{R p 3.000,00}{R p 2.600,00} \times 100 \%=115 \%(\text { dibulatkan })
$$

1. Penjualan akhir tahun 2005 sebesar $115 \%$ dari penjualan tahun 2003 .

2. Penjualan akhir tahun 2005 naik sebesar $15 \%$ jika dibandingkan dengan penjualan akhir tahun 2003. 
3. Penjualan akhir tahun 2005 berjumlah $15 \%$ lebih besar dan penjualan akhir tahun 2003.

Selanjutnya untuk penjualan pada akhir tahun 2006 sebesar Rp3.400 sedangkan penjualan tahun 2003 adalah Rp2.600 maka :

$$
\text { Angka Indeks }=\frac{R p 3.400,00}{R p 2.600,00} \times 100 \%=131 \%(\text { dibulatkan }) \backslash
$$

1. penjualan akhir tahun 2006 sebesar $131 \%$ dari penjualan tahun 2003

2. penjualan akhir tahun 2006 naik sebesar $31 \%$ jika dibandingkan dengan penjualan akhir tahun 2003

3. penjualan akhir tahun 2006 berjumlah $31 \%$ lebih besar dari penjualan akhir tahun 2003

Biaya penjualan pada akhir tahun 2004 sebesar Rp530.000 sedangkan biaya penjualan tahun 2003 adalah Rp500.000 maka :

$$
\text { Angka Indeks }=\frac{R p 530,00}{R p 500,00} \times 100 \%=106 \%
$$

1. Biaya penjualan akhir tahun 2004 sebesar $106 \%$ dari biaya penjualan tahun 2003

2. Biaya penjualan akhir tahun 2004 naik sebesar $6 \%$ jika dibandingkan dengan biaya penjualan akhir tahun 2003

3. Biaya penjualan akhir tahun 2004 berjumlah $6 \%$ lebih besar dari biaya penjualan akhir tahun 2003

Kemudian biaya penjualan pada akhir tahun 2005 sebesar Rp550.000 sedangkan biaya penjualan tahun 2003 adalah Rp500.000 maka :

$$
\text { Angka Indeks }=\frac{R p 550,00}{R p 500,00} \times 100 \%=110 \%
$$

1. Biaya penjualan akhir tahun 2005 sebesar $110 \%$ dari biaya penjualan tahun 2003

2. Biaya penjualan akhir tahun 2005 naik sebesar $10 \%$ jika dibandingkan dengan biaya penjualan akhir tahun 2003 
3. Biaya penjualan akhir tahun 2005 berjumlah $10 \%$ lebih besar dari biaya penjualan akhir tahun 2003

Untuk laba bersih pada akhir tahun 2004 sebesar Rp700 sedangkan penjualan tahun 2003 adalah Rp440.000 maka :

$$
\text { Angka Indeks } \left.=\frac{R p 700,00}{R p 440,00} \times 100 \%=160 \% \text { (dibulatkan }\right)
$$

1. Laba bersih akhir tahun 2004 sebesar $160 \%$ dari laba bersih tahun 2003

2. Laba bersih akhir tahun 2004 naik sebesar $60 \%$ jika dibandingkan dengan laba bersih akhir tahun 2003

3. Laba bersih akhir tahun 2004 berjumlah $60 \%$ lebih besar dari laba bersih akhir tahun 2003

Sementara itu untuk laba bersih pada akhir tahun 2005 sebesar Rp780.000 sedangkan penjualan tahun 2003 adalah Rp440.000 maka :

$$
\text { Angka Indeks }=\frac{R p 780,00}{R p 440,00} \times 100 \%=177 \%(\text { dibulatkan })
$$

1. Laba bersih akhir tahun 2005 sebesar $177 \%$ dari laba bersih tahun 2003

2. Laba bersih akhir tahun 2005 naik sebesar $77 \%$ jika dibandingkan dengan laba bersih akhir tahun 2003

3. Laba bersih akhir tahun 2005 berjumlah $77 \%$ lebih besar dan laba bersih air tahun 2003

Seterusnya dapat digunakan dengan model analisis diatas.

\section{F. Analisis Persentase Perkomponen}

Analisis persentase perkomponen merupakan teknik analisis laporan keuangan dengan menganalisis komponen-komponen yang ada dalam laporan keuangan baik yang ada di neraca maupun laporan laba rugi sebagai contoh adalah perbandingan antara aktiva dengan sediaan atau penjualan dengan komposisi biaya hasil analisis dibuatkan dalam bentuk persentase artinya mengubah jumlah rupiah dalam laporan keuangan menjadi persentase. 
Tujuan analisis persentase perkomponen adalah untuk mengetahui hal-hal antara lain.

1. Persentase investasi terhadap masing-masing aktiva atau terhadap pasiva

2. Struktur permodalan

3. Komposisi biaya terhadap penjualan

Analisis ini dilakukan dengan membandingkan setiap perubahan dalam pot pos dengan total aktiva atau total atau total penjualan dengan demikian akan terlihat suatu kenaikan atau penurunan apakah akan menjadi berarti atau memiliki makna tertentu.

Berikut persentase perkomponen yang diambil dari kedua laporan keuangan PT Ray Ibrahim Tbk di atas sebagai berikut.

1. Antara Komponen Piutang Dengan Total Aktiva

Analisis persentase perkomponen adalah :

Untuk tahun 2003:

$$
\begin{aligned}
& \frac{\text { Piutang }}{\text { Total Aktiva }} \times 100 \% \\
& \frac{R p 540,00}{R p 3.000,00} \times 100 \%=18 \%
\end{aligned}
$$

Artinya piutang tahun 2003 berjumlah 18\% dari jumlah aktiva dengan kata lain bahwa setiap Rp1,00 akibat investasikan ke piutang sebesar Rp0,18.

Untuk tahun 2004 :

$$
\frac{R p 680,00}{R p 3.400,00} \times 100 \%=20 \%
$$

Artinya piutang tahun 2004 berjumlah 20\% dari jumlah aktiva dengan kata lain bahwa setiap satu aktiva diinvestasikan utang sebesar Rp0,20

Untuk tahun 2005

$$
\frac{R p 500,00}{R p 3.650,00} \times 100 \%=14 \%(\text { dibulatkan })
$$


Artinya piutang tahun 2005 berjumlah 14\% dari jumlah aktiva dengan kata lain setiap Rp1,00 aktiva diinvestasikan ke piutang sebesar Rp0,14,00

Dari uraian di atas dapat dilihat bahwa investasi aktiva di piutang terjadi kenaikan 2\% tahun 2004 kemudian turun 4\% tahun 2005 jika dibandingkan dengan tahun 2004.

2. Antara Komponen Hutang Jangka Pendek Dengan Total Pasiva

Untuk tahun 2003 adalah :

$$
\begin{aligned}
& \frac{\text { Utang Jangka Pendek }}{\text { Total Passiva }} \times 100 \% \\
& \frac{R p 500,00}{R p 3.000,00} \times 100 \%=17 \% \text { (dibulatkan) }
\end{aligned}
$$

Artinya utang jangka pendek tahun 2003 berjumlah 17\% dari jumlah pasiva atau dengan kata lain setiap rp1 aktiva dibiayai dengan utang jangka pendek sebesar Rp0,17 atau Rp1,00 pasiva maka Rp0,17 merupakan utang jangka pendek

Untuk tahun 2004 :

$$
\frac{R p 530,00}{R p 3.400,00} \times 100 \%=16 \%(\text { dibulatkan })
$$

Artinya utang jangka pendek tahun 2004 berjumlah 16\% dari jumlah pasiva atau dengan kata lain setiap Rp1,00 aktiva dibiayai dengan utang jangka pendek sebesar Rp0,16 atau Rp1,00 pasiva maka Rp0,16 rupiah merupakan utang jangka pendek

Untuk tahun 2005 :

$$
\frac{R p 570,00}{R p 3.650,00} \times 100 \%=16 \%(\text { dibulatkan })
$$

Artinya utang jangka pendek tahun 2005 berjumlah 16\% dari jumlah pasiva atau dengan kata lain setiap rp1 aktiva dibiayai dengan utang jangka pendek sebesar rp16 atau rp1 pasiva makan rp16 merupakan utang jangka pendek 
Dari uraian di atas dapat dilihat bahwa aktiva yang dibiayai utang jangka pendek menurun tahun 2003 sebesar 1\% pada tahun 2004 dan tetap pada tahun 2005.

3. Antara Komponen Sediaan Dengan Total Aktiva

Untuk tahun 2003 :

$$
\begin{gathered}
\frac{\text { Sediaan }}{\text { Total Passiva }} \times 100 \% \\
\frac{R p 420,00}{R p 3.000,00} \times 100 \%=14 \%
\end{gathered}
$$

Artinya sediaan tahun 2003 berjumlah 14\% dari jumlah aktiva atau dengan kata lain setiap Rp1 aktiva investasikan pada sediaan sebesar Rp14

Untuk tahun 2004 :

$$
\frac{R p 560,00}{R p 3.400,00} \times 100 \%=16,5 \%
$$

Artinya sediaan tahun 2004 berjumlah 16,5\% dari jumlah aktiva atau dengan kata lain setiap Rp1 aktiva diinvestasikan pada sediaan sebesar Rp165

Untuk tahun 2005

$$
\frac{R p 800,00}{R p 3.650,00} \times 100 \%=22 \%
$$

Artinya sediaan tahun 2005 berjumlah 22\% dari jumlah aktiva atau dengan kata lain setiap Rp1 aktiva diinvestasikan kesediaan sebesar Rp22.

Dari uraian di atas dapat dilihat bahwa investasi aktiva disediakan terus meningkat dari 14\% tahun 2003 menjadi 16,5\% tahun 2004 dan menjadi 22\% tahun 2005 .

4. Antara Komponen Harga Pokok Penjualan Dengan Penjualan Bersih Untuk tahun 2003 : 


$$
\begin{gathered}
\frac{\text { Harga Pokok Penjualan }}{\text { Penjualan bersih }} \times 100 \% \\
\frac{R p 1.200,00}{R p 2.600,00} \times 100 \%=46 \% \text { (dibulatkan) }
\end{gathered}
$$

Artinya harga pokok penjualan tahun 2003 berjumlah 46\% dari jumlah penjualan bersih atau dengan kata lain setiap Rp1 penjualan bersih terkandung Rp46.000 harga pokok penjualan.

Untuk tahun 2004 :

$$
\frac{R p 1.350,00}{R p 2.850,00} \times 100 \%=47 \%(\text { dibulatkan })
$$

Artinya harga pokok penjualan tahun 2004 berjumlah 47\% dari jumlah penjualan bersih atau dengan kata lain setiap Rp1.000 penjualan bersih terkandung Rp47 harga pokok penjualan.

Untuk tahun 2005 :

$$
\frac{R p 1.400,00}{R p 3.000,00} \times 100 \%=47 \%(\text { dibulatkan })
$$

Artinya harga pokok penjualan tahun 2005 berjumlah 47\% dari jumlah penjualan bersih atau dengan kata lain setiap Rp1 penjualan bersih terkandung Rp47 harga pokok penjualan.

Dari uraian di atas dapat dilihat bahwa kandungan harga pokok penjualan di penjualan bersih meningkat 1\% dari tahun 2003 ke tahun 2004 demikian pula untuk tahun 2005 dengan jumlah yang sama.

5. Antara Komponen Laba Operasional Dengan Penjualan Bersih

Untuk tahun 2003 : 


$$
\begin{gathered}
\frac{\text { Laba Operasional }}{\text { Penjualan bersih }} \times 100 \% \\
\frac{R p 440,00}{R p 2.600,00} \times 100 \%=17 \% \text { (dibulatkan) }
\end{gathered}
$$

Artinya laba operasional tahun 2003 berjumlah 17\% dari jumlah penjualan bersih atau dengan kata lain setiap Rp1 penjualan bersih diperoleh Rp17 laba operasional

Untuk tahun 2004 :

$$
\frac{R p 700,00}{R p 2.850,00} \times 100 \%=25 \%(\text { dibulatkan })
$$

Artinya laba operasional tahun 2004 berjumlah 25\% dari jumlah penjualan bersih atau dengan kata lain setiap Rp1 penjualan bersih diperoleh Rp25 laba operasional.

Untuk tahun 2005 :

$$
\frac{R p 780,00}{R p 3.000,00} \times 100 \%=26 \%
$$

Artinya laba operasional tahun 2004 berjumlah 26\% dari jumlah penjualan bersih atau dengan kata lain setiap rp1 penjualan bersih diperoleh Rp26 laba operasional.

Dari uraian di atas dapat dilihat bahwa laba operasional perusahaan terus meningkat dari tahun 2003 sebesar 17\% menjadi 25\% pada tahun 2004 dan 26\% pada tahun 2005 .

Untuk pos-pos selanjutnya dari kedua laporan keuangan di atas dapat dihitung dengan cara yang sama.

Contoh menggunakan analisis ini misalnya kenaikan sediaan tahun 2005 sejumlah Rp800 menjadi sebesar Rp1.000 pada tahun 2006 menjadi berarti hal ini 
perlu dilihat dulu dengan membandingkan dengan total aktiva dimana pada tahun 2005 sebesar Rp3.650 dan tahun 2006 sebesar Rp4.200 dengan demikian analisis persentase panen adalah sebagai berikut.

Untuk tahun 2005:

Perbandingan sediaan:

$$
\begin{gathered}
\text { Angka Indeks }=\frac{R p 1.000,00}{R p 800,00} \times 100 \%=125 \% \\
\text { APP }=\frac{R p 800,00}{R p 3.650,00} \times 100=21,9 \% \text { dibulatkan }(22 \%)
\end{gathered}
$$

Ini berarti kenaikan sebesar $22 \%$

Untuk tahun 2006 adalah :

$$
\mathrm{APP}=\frac{R p 1.000,00}{R p 4.200,00} \times 100 \%=23,8 \% \text { dibulatkan }(24 \%)
$$

Dari data ini memang terlihat bahwa kenaikan sediaan diikuti oleh kenaikan persentase antara sediaan dengan total aktiva sehingga dianggap memiliki arti yang cukup baik. 


\section{BAB III \\ PENUTUP}

\section{A. Kesimpulan}

Dari pemaparan materi di atas, maka dapat ditarik kesimpulan bahwa :

1. Analisis laporan keuangan adalah suatu proses penelitian laporan keuangan beserta unsur-unsurnya yang bertujuan untuk mengevaluasi dan memprediksi kondisi keuangan perusahaan atau badan usaha dan juga mengevaluasi hasilhasil yang telah dicapai perusahaan atau badan usaha pada masa lalu dan sekarang.

2. Analisis laporan keuangan sangat penting untuk diterapkan dalam sistem suatu perusahaan karena dengan menggunakan analisis laporan keuangan ini perusahaan dapat mengetahui keuntungan dan kerugian yang dicapai perusahaan dalam suatu periode. Beberapa isu yang harus dipertimbangkan dalam analisis laporan keuangan agar laporan keuangan bisa diperbandingkan. Analisis berdasarkan laporan keuangan yang melibatkan beberapa perbandingan baik terhadap perusahaan lainnya atau terhadap data pada periode-periodde sebelumnya.

3. Seorang analisis dalam melakukan analisis laporan keuangan harus melakukan beberapa langkah yaitu:

a. Menentukan tujuan dari analisis laporan keuangan.

b. Memahami konsep-konsep dan prinsip-prinsip yang mendasari laporan keuangan.

c. Memahami kondisi ekonomi dan bisnis yang mempengaruhi usaha perusahaan tersebut.

\section{B. Saran}

Dengan disusunnya makalah ini, dari penulis berharap agar para pembaca khususnya mahasiswa dapat mengerti dan memahami Analisis Laporan Keuangan. 


\section{DAFTAR PUSTAKA}

Kasmir. 2018. Analisis Laporan Keuangan. Depok: Rajawali Pers.

Ismawati, I. PASAR UANG DALAM PERSPEKTIF ISLAM. Jurnal Minds: Manajemen Ide dan Inspirasi, 3(1), 96-106.

Mustamin, A., Ismawati, I., \& Trimulato, T. (2020). Analisis Kinerja Keuangan untuk Menilai Keunggulan Bersaing pada Bank Syariah Mandiri Indonesia. JURNAL HUKUM EKONOMI SYARIAH, 3(1), 51-64.

Trimulato, T., Mustamin, A., \& Ismawati, I. (2020). Service Excellent Bagi Fintech Syariah di Tengah Kondisi Covid-19. Al-Mizan: Jurnal Hukum dan Ekonomi Islam, 4(2), 13-36.

Trimulato, T., Ismawati, I., Amiruddin, K., \& Nuraeni, N. (2020). Penguatan Peran Ekonomi Islam Melalui Optimalisasi Pembiayaan pada Sektor Riil UMKM. JES (Jurnal Ekonomi Syariah), 5(2).

Prihadi, T. (2019). Analisis Laporan Keuangan. Gramedia Pustaka Utama.

Subramayan, K. R. (2010). Analisis laporan keuangan.

Maith, H. A. (2013). Analisis Laporan Keuangan dalam Mengukur Kinerja Keuangan pada PT. Hanjaya Mandala Sampoerna Tbk. Jurnal EMBA: Jurnal Riset Ekonomi, Manajemen, Bisnis dan Akuntansi, 1(3).

Pongoh, M. (2013). Analisis Laporan Keuangan untuk Menilai Kinerja Keuangan PT. Bumi Resources Tbk. Jurnal EMBA: Jurnal Riset Ekonomi, Manajemen, Bisnis dan Akuntansi, 1(3).

Murhadi, W. R. (2013). Analisis Laporan Keuangan: Proyeksi dan Valuasi Saham.

Sujarweni, V. W. (2017). Analisis Laporan Keuangan; Teori, Aplikasi, dan Hasil Penelitian.

Tanor, M. O., Sabijono, H., \& Walandouw, S. K. (2015). Analisis laporan keuangan dalam mengukur kinerja keuangan pada pt. Bank Artha Graha Internasional, Tbk. Jurnal EMBA: Jurnal Riset Ekonomi, Manajemen, Bisnis dan Akuntansi, 3(3). 
Septiana, A. (2019). Analisis laporan keuangan konsep dasar dan deskripsi laporan keuangan (Vol. 96). Duta Media Publishing.

Ottay, M. C., \& Alexander, S. W. (2015). Analisis laporan keuangan untuk menilai kinerja keuangan pada PT. BPR Citra Dumoga Manado. Jurnal Emba: Jurnal Riset Ekonomi, Manajemen, Bisnis Dan Akuntansi, 3(1).

Sukamulja, S. (2019). Analisis laporan keuangan sebagai dasar pengambilan keputusan investasi. 